J. Clin. Chem. Clin. Biochem.

Vol. 22, 1984, pp. 585-589

\title{
Frequency of Apolipoprotein A-I Mutants in the German Population
}

\author{
By G. Assmann, H.J. Menzel \\ Institut für Klinische Chemie und Laboratoriumsmedizin (Zentrallaboratorium) \\ der Medizinischen Einrichtungen der Westfälischen Wilhelms-Universität Münster
}

R. G. Kladetzky

Medizinische Klinik, Abteilung für Kardiologie der Universität Düsseldorf and

G. Büttner

Institut für Klinische Chemie und Laboratoriumsmedizin (Zentrallaboratorium) der Medizinischen Einrichtungen der Westfälischen Wilhelms-Universität Münster

(Received December 21, 1983/March 15, 1984)

Summary: A randomly chosen population in the area of Westphalia (West Germany) was screened for apolipoprotein A-I mutants. About 5000 individuals were investigated and compared with a group of 1300 patients who had undergone coronary angiography. Four electrophoretically different apolipoprotein A-Imutants (named Münster-1 to 4) were discovered. Five non-related probands were observed in the group of the unselected patients and three non-related probands in the group of coronary angiography patients. In most cases the familial nature of the abnormality was confirmed by pedigree analysis.

\section{Zur Häufigkeit von Apolipoprotein A-I-Mutanten in der deutschen Bevölkerung}

Zusammenfassung: Eine Bevölkerungsgruppe von 5000 Personen in Westfalen sowie eine Gruppe von 1300 koronarangiographierten Personen wurde mittels isoelektrischer Fokussierung von Nativserum auf Apolipoprotein A-I-Mutanten untersucht. Es wurden bei insgesamt 8 Probanden (davon 5 in der Gruppe der zufällig ausgewählten Patienten und 3 in der Gruppe der koronarangiographierten Patienten) 4 isoelektrisch verschiedene Mutantẹn (gẹnannt Münster-1 bis 4) gefunden. In den meisten Fällen wurde das familiäre Vorliegen der Mutation mittels Stammbaumanalyse bestätigt.

\section{Introduction}

Many apolipoproteins exist in electrophoretically different forms. This has been shown for apolipoprotein E (1), apolipoprotein A-IV (2), and apolipoprotein C-II (3). For apolipoprotein E and A-IV these mutant forms occur rather commonly in the normal population with a frequency of $1-2 \%$ for the homozygous state $(1,2)$. In the case of apolipoprotein A-I only a few rare cases of mutations have been described, e.g. A-I-Milano (4, 5), A-I-Marburg and A-I-Gießen (6), and A-I-Münster 1-3 (7).
The occurrence of apolipoprotein mutations could give new information about the function of normal apolipoproteins in lipid metabolism, as already demonstrated for apolipoprotein E (8). Since a malfunction of lipid metabolism might also be related to cardiovascular disease (9), we investigated the occurrence of apolipoprotein A-I mutations in both an unselected population, and in a group of patients with a history of coronary artery disease. 


\section{Materials and Methods}

Patients

Sera from paticnts were collected in connection with a prospective cardiovascular study in the area of Westphalia, West Germany (10). Sera of paticnts who had undergone coronary angiography were supplied by the Department of Cardiology, University of Düsseldorf, West Germany. Either fresh or frozen $\left(-20^{\circ} \mathrm{C}\right)$ sera were used.

\section{Isoelectric focusing}

The serum was incubated in the presence of decylsulphate and $\beta$ mercaptoethanol and subjected to isoelectric focusing in a $\mathrm{pH}$ gradient from 4-6 (7). After facusing overnight the gels were stained with Coomassie brillant blue.

For two dimensional immunelectrophoresis the gel strips were cut after isoelectric focusing, and agarose containing specific anti apolipoprotein A-I antibodies (Behringwerke, Marburg) was poured onto a plastic cover around the strips. After electrophoresis the plates were washed, and the immunoprecipitates stained with Coomassie (7). Lipoproteins were isolated by ultracentrifugation according to Havel et al. (11).

\section{Cyanogen brömide hydrolysis}

For analytical purposes, the pure apolipoprotein A-I isoforms were precipitated with $100 \mathrm{~g} / \mathrm{t}$ trichloroacetic acid to remove the ampholytes and washed 3 times with $100 \mathrm{~g} / \mathrm{l}$ trichloroacetic acid at $0^{\circ} \mathrm{C}$. The trichloroacetic acid was removed from the precipitated protein by ice-cold acetone. The protein was solubilized in $10 \mathrm{~g} / 1$ formic acid and $10 \mathrm{~g} / \mathrm{l}$ decylsulphate and $\mathrm{CNBr}$ was added in a 500 -fold molar excess over the methionine content ( 1500 molar ratio to apolipoprotein A-I) and incubated for $24 \mathrm{~h}$ at $25^{\circ} \mathrm{C}$. The $\mathrm{CNBr}$ peptides were lyophilized and subjected to isoelectric focusing in a $\mathrm{pH}$ gradient of 3.5 to 10 . After separation by isoelectric focusing, the peptides were analysed in the second dimension by sodium dodecyl sulphate gel electrophoresis to determine their molecular weight.

\section{Results}

Isoelectric focusing of normal serum in a $\mathrm{pH}$ gradient from 4-6 reveals up to 15 bands, of which the most predominant one is apolipoprotein A-I (fig. 1, lanes $A$ and $K$ ). In addition to the major isoform of apolipoprotein A-I (apolipoprotein A-I-1), which accounts for about $90 \%$ of total apolipoprotein A-I, a minor isoform (apolipoprotein A-I-2) with a serum concentration of about $8 \%$ of total apolipoprotein A-I is also observed (9).

In addition to these normal isoforms of apolipoprotein A-I, we detected some rare cases of electrophoretic variants of apolipoprotein A-I (fig. 1, lanes B to J). Identification as apolipoprotein A-I was based upon molecular weight determination by SDS electrophoresis, immunoreactivity against monospecific apolipoprotein A-I antibodies in two-dimensional immunoelectrophoresis and amino acid analysis. We distinguished between four electrophoretically different mutants, designated apolipoprotein A-IMünster-1 to apolipoprotein A-I-Münster-4. As

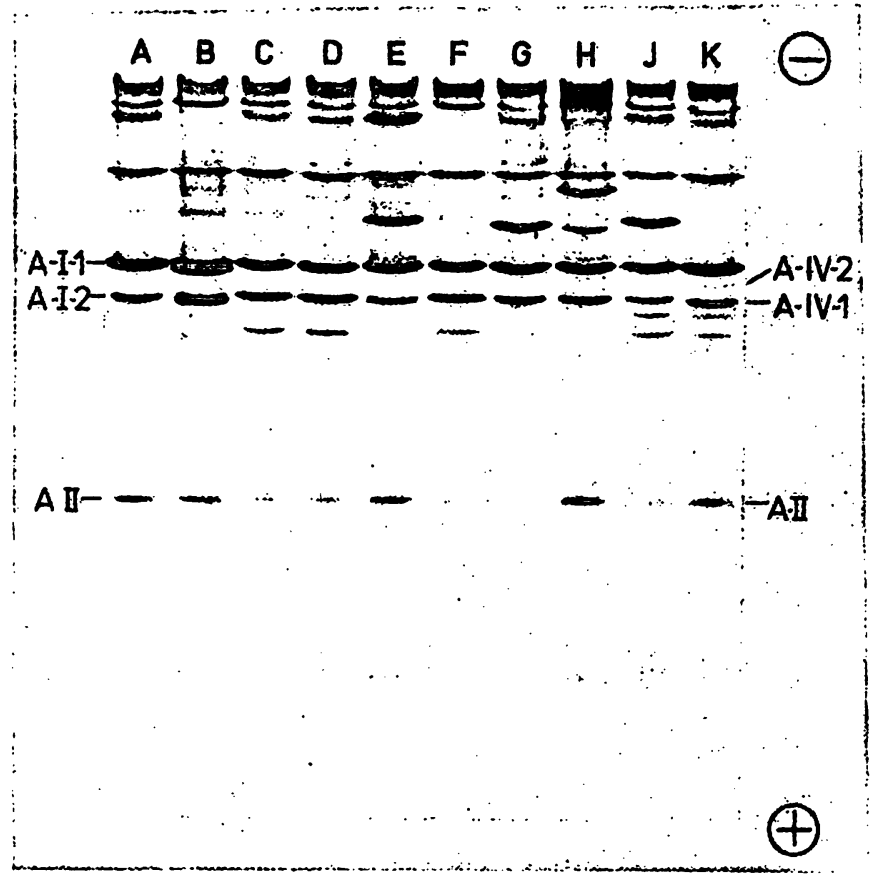

Fig. 1. Isoelectric focusing of normal serum $(A, K)$ and serum of

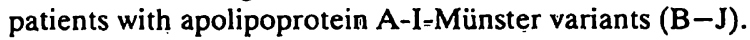
A-I, A-II, A-IV = Apolipoprotein A-I, A-II, A-IV.

evaluated by two-dimensional immunoelectrophoresis, the serum concentrations of the normal apolipoprotein A-I and the mutant apolipoprotein A-I were usually similar. In 5 families (table 1, proband 1, 2, $3,5,7)$ the apolipoprotein variant was observed in several family members. In 3 families $(4,6,8)$, no evidence for the familial nature of the mutation could be established, owing to the limited number of first-degree relatives available for investigation.

Isoelectric focusing of the serum of the proband affected by the apolipoprotein A-I-Münster-1 variant (F.Fr.) reveals two apolipoprotein $A-I$ bands very close to each other (fig. 1, lane B), the upper being the normal apolipoprotein A-I, the lower being the mutant apolipoprotein A-I-Münster-1. This mutation was observed in a single family. The apolipoprotein A-I-Münster-2 variant, which migrates in the position of apolipoprotein A-I-2 (minor isoform of apolipoprotein A-I-1), was observed in three nonrelated probands (fig. 1, lanes C, D and F): Probands with the more basic mutant apolipoprotein A-IMünster-3 were also observed in three non-related probands (fig. 1, lanes E, G and J). The apolipoprotein A-I-Münster-2 variant and apolipoprotein A-IMünster-3 variant differ by 1 charge unit $(-1$ and +1 , respectively) from normal apolipoprotein A-I. Only one proband was discovered with a mutant apolipoprotein A-I which differed by two charge units from normal apolipoprotein A-I (apolipoprotein A-I-Münster-4) (fig. 1, läne H). 
Tab. 1. Some characteristics of the eight detected probands suffering from apolipoprotein A-I mutants.

\begin{tabular}{|c|c|c|c|c|c|c|c|}
\hline Proband & Mutant & $\begin{array}{l}\text { Affected } \\
\text { CNBr fragment }\end{array}$ & $\begin{array}{l}\text { Age } \\
\text { (a) }\end{array}$ & $\begin{array}{l}\text { Affected family } \\
\text { members } \\
\text { (N) }\end{array}$ & $\begin{array}{l}\text { Cholesterol } \\
(\mathrm{mmol} / \mathrm{l})\end{array}$ & $\begin{array}{l}\text { Triglycerides } \\
\text { (mmol/l) }\end{array}$ & $\begin{array}{l}\text { HDL } \\
\text { Cholesterol } \\
(\mathrm{mmol} / \mathrm{l})\end{array}$ \\
\hline $\begin{array}{l}\text { 1. F.Fr. } \\
\text { 2. G.Fu. } \\
\text { 3. C.D. } \\
\text { 4. G.E. } \\
\text { 5. H.H. } \\
\text { 6. M.K. } \\
\text { 7. H.B. } \\
\text { 8. A.R. }\end{array}$ & $\begin{array}{l}\text { Al Münster-1 } \\
\text { Al Münster-2 } \\
\text { Al Münster-2 } \\
\text { Al Münster-2 } \\
\text { Al Münster-3 } \\
\text { Al Münster-3 } \\
\text { Al Münster-3 } \\
\text { Al Münster-4 }\end{array}$ & $\begin{array}{l}\text { CB-4 } \\
\text { CB-4 } \\
\text { CB-2 } \\
\text { CB-2 } \\
\text { CB-1 } \\
\text { CB-2 } \\
\text { CB-4 } \\
\text { CB-4 }\end{array}$ & $\begin{array}{l}47 \\
22 \\
54 \\
48 \\
56 \\
38 \\
27 \\
37\end{array}$ & $\begin{array}{cc}10 & (23)^{*} \\
4 & (4) \\
9 & (23) \\
1 & (3) \\
5 & (9) \\
1 & (3) \\
4 & (5) \\
1 & (1)\end{array}$ & $\begin{array}{l}6.83 \\
4.97 \\
5.22 \\
9.54 \\
5.51 \\
4.50 \\
5.25 \\
7.89\end{array}$ & $\begin{array}{l}3.47 \\
1.78 \\
1.02 \\
2.98 \\
2.61 \\
0.83 \\
1.05 \\
0.79\end{array}$ & $\begin{array}{l}0.98 \\
0.91 \\
1.34 \\
1.09 \\
0.91 \\
1.32 \\
1.06 \\
1.11\end{array}$ \\
\hline
\end{tabular}

* The numbers in brackets indicate the numbers of first degree relatives investigated.

In each case the affected $\mathrm{CNBr}$ fragment was identified by isoelectric focusing of the apolipoprotein AI-CNBr-peptides (fig. 2). As summarized in table 1, probands 2 and 3 , which are both affected by the apolipoprotein A-I-Münster-2 variant, do not share the same molecular defect. Similarly, probands 5, 6 and 7, all affected by the apolipoprotein A-I-Münster- 3 variant, exhibit the amino acid defect in different $\mathrm{CNBr}$-peptides.
In the group of 5000 non-selected individuals we detected two probands with the apolipoprotein A-IMünster-2 variant, two probands with the apolipoprotein A-I-Münster-3 variant and one with apolipoprotein A-I-Münster-4 variant. The other probands affected by apolipoprotein A-I variants were observed in the group of coronary angiography patients. Owing to the limited number of probands in the group of coronary angiography patients it is diffi-

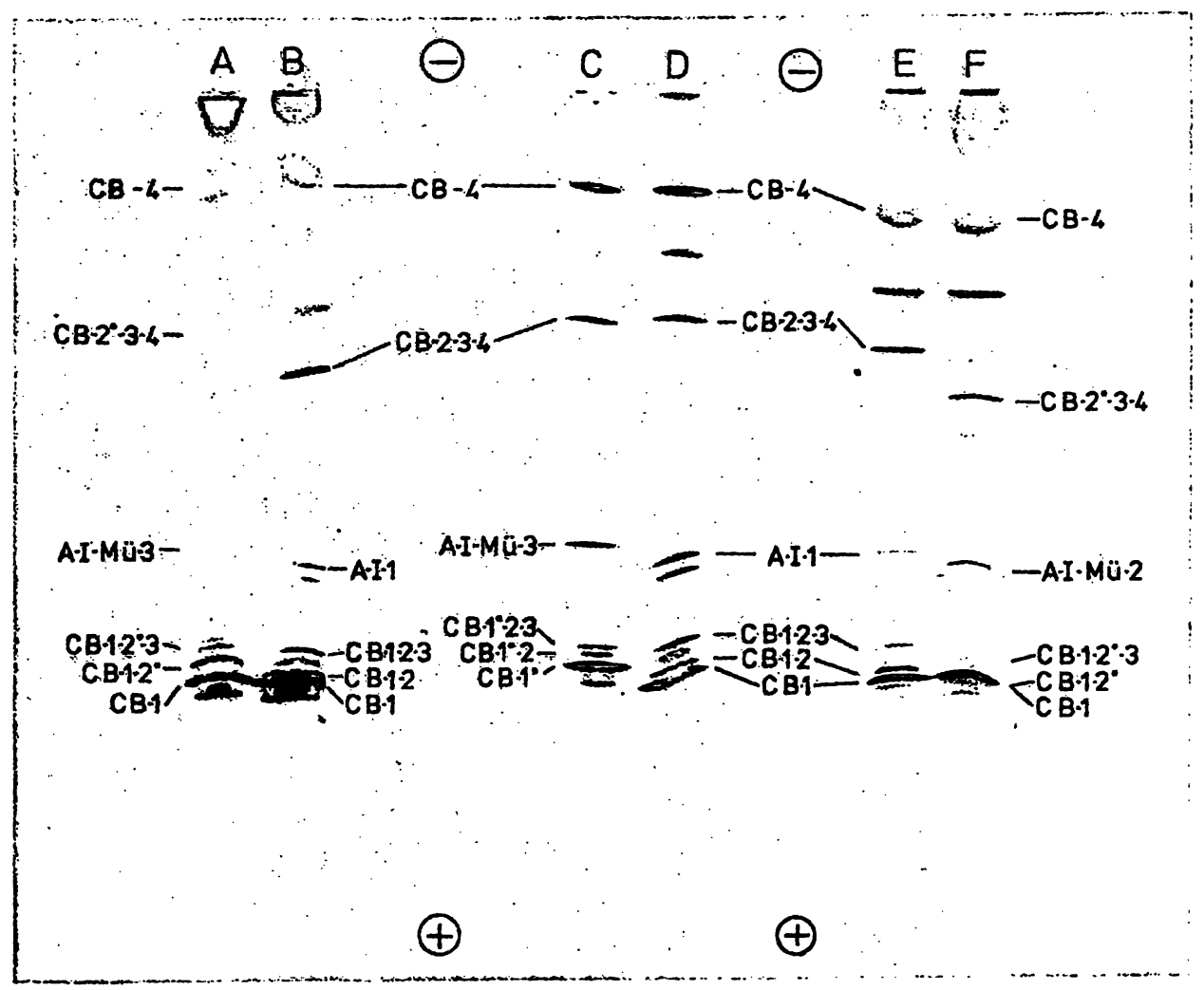

Fig. 2. Isoelectric focusing of the cyanogen bromide (CB) peptides from the apolipoprotein A-I-Münster-3 (A-1-Mü-3) from individuals M.K. and H.H. (A, C), from the apolipoprotein A-I-Münster-2 (A-I-Mü-2), from individual G.E. (F) and from control persons $(\mathrm{B}, \mathrm{D}, \mathrm{E})$.

Isoelectric focusing was performed in a $\mathrm{pH}$ gradient of 3.5 to 10 . The nomenclature of cyanogen bromide peptides is according to Brewer et al. (14), and identification was based on the molecular weight determination (second dimension, SDS gels, not shown) and on the isoelectric focusing position. 
cult to ascertain whether or not the apolipoprotein mutation relates to the occurrence of coronary heart disease. In the case of the apolipoprotein A-I-Münster-1 variant (F.Fr.) the proband and his affected brother both had developed severe premature coronary artery disease, but they were also E $2 / 2$ homozygotes with slightly elevated lipid values. One patient affected by the apolipoprotein A-I-Münster-2 variant (C.D.) had heart valve failure, whereas the patient with apolipoprotein A-I-Münster-3 variant (H.H.) suffered from premature coronary artery disease.

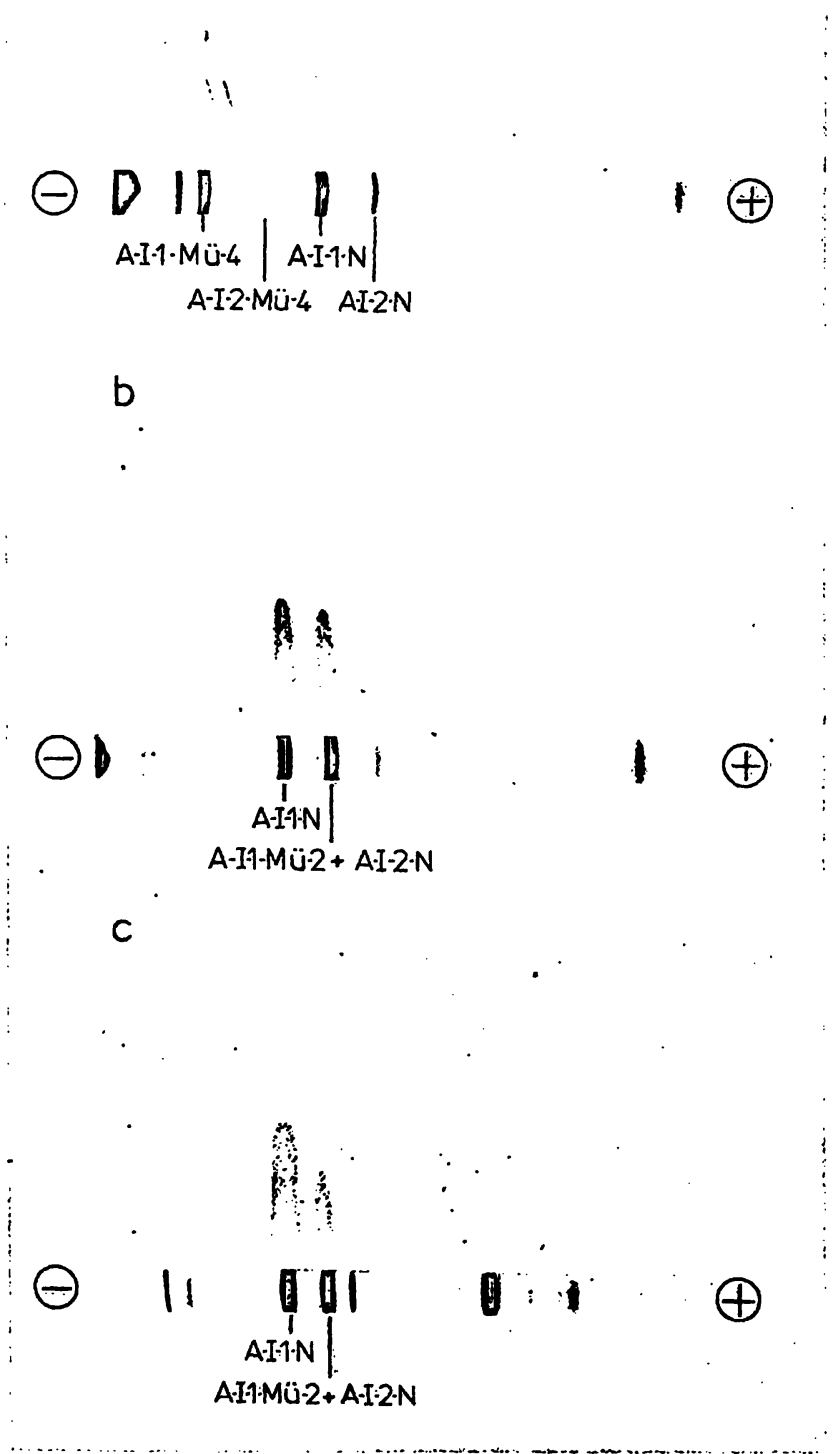

Fig. 3. Crossed immunoelectrophoresis after isoelectric focusing against anti-apolipoprotein A-I (7).

a) apolipoprotein A-I-Münster-4 variant, native serum

b) apolipoprotein A-I-Münster-2 variant, native serum, patient G.Fu.

c) apolipoprotein A-I-Münster-2 variant, ultracentrifugally isolated $\mathrm{HDL}$, patient G.Fu.
Information was also obtained about the ability of the various apolipoprotein A-I-mutants to express normal function with respect to lipid binding and/or protein-protein interaction within high density lipoproteins (HDL). The ratio of the normal and mutant apolipoprotein A-I was determined in serum as well as HDL by two-dimensional immuno-electrophoresis; in nearly all cases the ratio was about $1: 1$ in both native serum and HDL. This is demonstrated for the apolipoprotein A-I-Münster-4 variant in figure 3. In contrast to these regular findings in one family with the apolipoprotein A-I-Münster-2 variant, the native sera of the affected family members exhibit a ratio of 5:3 (normal to mutant apolipoprotein A-I) and the HDL exhibit a ratio of 7:2 (fig. $3, b$ and c). Preferential displacement of the mutant apolipoprotein A-I-Münster-2 (proband G.Fu.) from HDL apparently occurred during ultracentrifugal isolation, as evidenced by the $2: 7$ ratio (normal to mutant apolipoprotein $\mathrm{A}-\mathrm{I}$ ) in the $\mathrm{d}>1.21 \mathrm{~kg} / \mathrm{l}$ ultracentrifugal fraction (not shown).

\section{Discussion}

With the isoelectric focusing technique described here four different electrophoretic mutants of apolipoprotein A-I occurring in eight non-related probands were discovered in a screening program involving approx. 6300 patients. Since different point mutations may cause an identical charge shift, molecular heterogeneity within eäch of the Münster variants can be predicted. This was demonstrated by $\mathrm{CNBr}$ peptide analysis of the Münster- 2 and Münster-3 variants as indicated in table 1 .

Discovery of these apolipoprotein A-I mutants is of great interest for the further understanding of structure-function relationships of this apolipoprotein. Isolated normal apolipoprotein A-I has the capacity to bind phospholipid, to reassociate with HDL, and to activate the enzyme lecithin-cholesterol acyltransferase (12). The molecular requirements. of phospholipid binding relate to hydrophobic interaction of the fatty acid moiety and hydrophobic surface areas of amphipathic helices within the apolipoprotein. The molecular requirements of reassociation of apolipoprotein A-I with HDL as well as lecithin-cholesterol acyltransferase activation are less well understood (13).

It was of interest to notice that in one family affected by the Münster-2 variant the mutant apolipoprotein A-I occurred in lower serum concentrations than the normal apolipoprotein. This discrepancy 
was more pronounced in ultracentrifugally isolated HDL, suggesting that the mutant apolipoprotein A-I was more vulnerable to displacement.

A detailed study of the precise molecular defect in the various apolipoprotein A-I mutants has now been performed. Preliminary sequence information suggests that two of the Münster-3 variants are caused by different molecular defects. In proband 5 an amino acid exchange was observed in position 4 (Pro $\rightarrow$ Arg), whereas in proband 6 the charge difference of the mutant apolipoprotein A-I is due to Asp $\rightarrow$ Asn exchange in position 103 (15). In two non-related probands affected by the Münster- 2 variant a lysine deletion was noticed in position 107 (Rall, S. \& Mahley, R. W., personal information). However, these preliminary sequence data relate at present only to the electrophoretically abnormal

\section{References}

1. Utermann, G., Jaeschke, M. \& Menzel, H. J. (1975) FEBS Letters 56, 352-355.

2. Menzel, H. J., Kövary, P. M. \& Assmann, G. (1982) Human Genet. 62, 349-352.

3. Havel, R. J., Kotite, L. \& Kane, J. P. (1979) Biochem. Med. $21,121-138$.

4. Franceschini, G., Sitori, C. R., Capurso, A., Weisgraber, K. H. \& Mahley, R. W. (1980) J. Clin. Invest. 66, 892-900.

5. Weisgraber, K. H., Bersot, T. P., Mahley, R. W., Franceschini, G. \& Sitori, C. R. (1980) J. Clin. Invest. 66, 901-907.

6. Utermann, G., Feusner, G., Haas, J. \& Steinmetz, A. (1981) J. Biol. Chem. 257, 501-507.

7. Menzel, H. J., Kladetzky, R. G. \& Assmann, G. (1982) J. Lipid Res. 23, 915-922.

8. Rall, S. C. Jr., Weisgraber, K. H., Innerarity, T. L. \& Mahley, R. W. (1982) Proc. Natl. Acad. Sci. USA 79, 4696-4700.

9. Menzel, H. J., Kladetzky, R. G. \& Assmann, G. (1983) Arteriosclerosis $3,315-310$.
$\mathrm{CNBr}$ peptides and full sequence analysis or DNA analysis may be required to exclude the possibility of the existence of further structural changes relevant to functional abnormalities.

Whether or not certain apolipoprotein A-I mutants may cause abnormalities of lipoprotein metabolism is currently under investigation. Due to the limited number of affected families and the possible coexistence of other lipid-modifying genetic defects, such functional data are difficult to obtain. In particular, the possible relationship of apolipoprotein A-I mutants to the development of coronary artery disease requires much further information. Nevertheless, it can be anticipated that detailed further structural knowledge of these mutants will give a clue as to the critical domains in the primary structure of apolipoprotein A-I.

10. Assmann, G., Oberwittler, W., Schulte, H., Schriewer, H., Funke, H., Epping, P. H. \& Hauss, W. H. (1980) Internist 21 . 446-459.

11. Havel, R. J., Eder, H. A. \& Bragdon, J. H. (1955) J. Clin. Invest. 34, 1345-1352.

12. Jackson, R. L., Morrisett, J. D. \& Gotto, A. M. Jr. (1977) Lipoproteins and lipid transport: Structural and functional concepts. In: Hyperlipidemia, Diagnosis and Therapy (Levy, R. I. \& Rifkind, B. M., eds.), Grune and Stratton, New York, p. 1.

13. Albers, J. J. (1979) Artery 5, 61.

14. Brewer, H. B. Jr., Fairwell, T., LaRue, A., Ronan, R., Houser, A. \& Bronżert, T. J. (1978) Biochem. Biophys. Res. Commun. 80, 623-630.

15. Menzel, H. J., Assmann, G., Rall, S. C., Weisgraber, K. H. \& Mahley, R. W. (1984) J. Biol. Chem., in press.

Prof. Dr. G. Assmann

Institut für Klinische Chemie und

Laboratoriumsmedizin (Zentrallaboratorium)

Medizinische Einrichtungen der

Westfälischen Wilhelms-Universität

Albert-Schweitzer-Straße 33

D-4400 Münster 
$\checkmark$

。

.

- 